University of Warwick institutional repository: http://go.warwick.ac.uk/wrap

This paper is made available online in accordance with publisher policies. Please scroll down to view the document itself. Please refer to the repository record for this item and our policy information available from the repository home page for further information.

To see the final version of this paper please visit the publisher's website. Access to the published version may require a subscription.

Author(s): Cappuccio, F. P., Capewell, S., Lincoln, P. and McPherson, $\mathrm{K}$.

Article Title: Policy options to reduce population salt intake

Year of publication: 2011

Link to published article:

http://dx.doi.org/10.1136/bmj.d4995

Publisher statement: None 


\section{Policy options to reduce population salt intake}

High dietary salt has detrimental effects on blood pressure and cardiovascular outcomes. The question, say Francesco Cappuccio and colleagues, is not whether to reduce salt intake but how to do so. With the upcoming United Nations High Level Meeting on non-communicable diseases in mind, they make the case for population level policy interventions.

\section{Francesco P Cappuccio Cephalon professor of cardiovascular medicine and epidemiology, head of WHO collaborating centre ${ }^{1}$, Simon Capewell chair of clinical epidemiology ${ }^{2}$, Paul Lincoln chief executive ${ }^{3}$, Klim McPherson visiting professor of public health epidemiology ${ }^{4}$}

${ }^{1}$ University of Warwick, Warwick Medical School, WHO Collaborating Centre for Nutrition, Coventry CV2 2DX, UK; ${ }^{2}$ University of Liverpool, Liverpool, UK; ${ }^{3}$ National Heart Forum, London, UK; ${ }^{4}$ University of Oxford, Oxford, UK

\section{Blood pressure and cardiovascular disease}

Raised blood pressure is the dominant cause of death and disability in adults worldwide, ${ }^{1}$ responsible for approximately $50 \%$ of deaths from coronary heart disease and over $60 \%$ of those from stroke. The risk of cardiovascular disease increases with increasing blood pressure, ${ }^{2}$ and causality is supported by randomised controlled clinical trials, in which lowering blood pressure over five years reduces cardiovascular disease by approximately the amount predicted from larger observational studies. ${ }^{3}$ But the majority of cardiovascular disease events attributable to blood pressure occur in people with untreated "normal" pressure (about 130/80 mm Hg), with additional events occurring even with blood pressure levels down to $115 / 75 \mathrm{~mm}$ Hg. ${ }^{2}$ Even a small downward shift in the distribution of blood pressure in the whole population would achieve a large drop in cardiovascular disease. ${ }^{2}$

\section{Evidence relating salt to blood pressure}

Evidence from a very wide variety of studies shows a consistent direct relation between salt intake and blood pressure. A $4.6 \mathrm{~g}$ reduction in daily dietary intake of salt (equivalent to a 1840 $\mathrm{mg}$ reduction in daily sodium) decreases blood pressure by about $5.0 / 2.7 \mathrm{~mm} \mathrm{Hg}$ in individuals with hypertension and by $2.0 / 1.0$ $\mathrm{mm} \mathrm{Hg}$ in normotensive people. ${ }^{4}$ Randomised controlled trials have consistently shown dose-response effects. ${ }^{5}$ The blood pressure lowering effect of reducing salt intake is effective in men and women, in all ethnic groups, in all age groups, and all starting blood pressures.
Population based interventions indicate that when salt intake is reduced, blood pressure in the community falls. An intervention study in two Portuguese villages over two years achieved a difference between intervention and control villages of about $50 \%$ in salt intake and a difference of $13 / 6 \mathrm{~mm} \mathrm{Hg}$ in blood pressure. ${ }^{6}$ A randomised community based intervention trial in villages in northeastern Japan, which tested the effects of dietary counselling for one year, reduced mean salt intake by $2.3 \mathrm{~g} / \mathrm{day}$ ( $920 \mathrm{mg}$ of sodium) as measured by $24 \mathrm{~h}$ urinary sodium, and was associated with a decrease of $3.1 \mathrm{~mm} \mathrm{Hg}$ in systolic blood pressure. ${ }^{7}$ Citizens in most countries eat salt far in excess of healthy physiological requirements (about $1 \mathrm{~g}$ per day).

\section{Evidence relating salt to cardiovascular disease}

No randomised controlled trials have studied the effect of reducing the salt intake of populations on cardiovascular disease - the ethical and methodological problems with such trials are similar to those with trials involving tobacco and obesity $^{8}$ - but the link is strong and is now accepted. In cohort studies, a $5 \mathrm{~g}$ per day higher salt intake ( $2000 \mathrm{mg}$ of sodium) is associated with a $17 \%$ greater risk of total cardiovascular disease, and, crucially a $23 \%$ greater risk of stroke. ${ }^{9}$

Since the 1970s, Finland has aimed to reduce the population's salt intake ${ }^{10}$ by collaboration with the food industry to develop food products with reduced salt and by raising awareness among consumers. Over 30 years salt intake has reduced by a third ( 6 $\mathrm{g}$ per person per day). Systolic blood pressure fell by over 10 $\mathrm{mm} \mathrm{Hg}$, while mortality from stroke and coronary heart disease decreased $75-80 \%$, with an increase of five to six years in life 
expectancy. ${ }^{10}$ Similarly, in Japan, a government campaign to reduce salt intake saw a fall from $13.5 \mathrm{~g} /$ day to $12.1 \mathrm{~g} /$ day (from $5400 \mathrm{mg}$ to $4840 \mathrm{mg}$ sodium) in a decade. This was associated with a substantial reduction in stroke mortality, ${ }^{11}$ despite increases in the population's fat intake, cigarette smoking, alcohol consumption, and body mass index.

\section{The economic imperative}

All countries need to satisfy stringent cost effectiveness criteria within a general climate of ageing populations, escalating healthcare demands, and recently reduced financial resources. Several economic modelling studies have assessed the health effects and financial cost of reducing population salt intake. Despite methodological differences, they all have consistently shown that a reduction in salt intake is associated with substantial cost savings (see webtable and web references ${ }^{\text {w1-w12}}$ ). For example, in the United States, a mean population salt reduction of $3 \mathrm{~g}$ per day would result in an estimated annual gain of 194 000-392 000 quality adjusted life years (QALYs), a measure of added healthy life, and savings of $\$ 10 \mathrm{bn}$ to $\$ 24 \mathrm{bn}$ (£6-15bn, €7-17bn) in healthcare costs. ${ }^{\text {w11 }}$ This represents a \$6-12 return on investment for each dollar spent on the regulatory programme. Cost savings are also estimated for a reduction in salt intake of $15 \%$ in low and middle income countries, with 13.8 million deaths averted over 10 years at an initial cost of less than $\$ 0.40$ per person per year. ${ }^{\text {w5 }}$

\section{The prevention imperative}

Unsurprisingly, the prevention of cardiovascular disease is now agreed as a top priority for action worldwide. ${ }^{12}$ Among the five priority interventions, reduction of populations' salt intake is listed as second after global tobacco control. It is estimated that a $15 \%$ reduction in salt intake would avert 8.5 million deaths over 10 years worldwide.

The global goal set by WHO is to reduce salt intake to less than $5 \mathrm{~g}$ (2000 mg of sodium) per person per day by $2025,{ }^{12}$ with some countries aiming for even lower levels in the longer term (table 1). ${ }^{\text {w13-w20 }}$ Progress towards this target could begin through mass media campaigns and reformulation of existing and new food products by industry. Since in most developed economies the majority of dietary salt is added during commercial food production, government regulation will also be needed. ${ }^{12} 13$

Many countries have committed themselves to salt reduction initiatives, often led by government, sometimes led by non-governmental organisations, but rarely led by industry (table 2). ${ }^{14}$ In 2004 the British government, through the Food Standards Agency, started a programme of population salt reduction through a media campaign to increase public awareness and demand for change, engagement with the food industry on a voluntary basis to set targets for sodium content in foods, and to obtain reformulation of many common food categories, and repeated national surveys using $24 \mathrm{~h}$ urine collections to monitor intake. Ministers also proposed legislation if the industry refused to make reductions voluntarily. As a result the mean salt intake in the UK fell from $9.5 \mathrm{~g} \mathrm{(3800} \mathrm{mg} \mathrm{sodium)} \mathrm{per} \mathrm{day} \mathrm{in} 2001$ to $8.6 \mathrm{~g}$ (3440 mg sodium) per day in 2008. In England and Wales, the government target is now $6 \mathrm{~g}$ ( $2400 \mathrm{mg}$ sodium) per day by 2012 , sadly remaining higher than the target of $4 \mathrm{~g} \mathrm{(1600} \mathrm{mg}$ sodium) per day achieved in the US DASH trial and of $3 \mathrm{~g}$ (1200 mg sodium) recommended by NICE by $2025 .{ }^{15}$ A reduction of $3 \mathrm{~g}$ per day in salt intake would result in a blood pressure fall of at least $2.5 / 1.4 \mathrm{~mm} \mathrm{Hg} .{ }^{15}$ This would reduce strokes by about $12-14 \%$ and coronary heart disease by $9-10 \%,{ }^{915}$ equivalent to approximately 6500-8000 deaths from stroke and 7500-12 000 deaths from coronary heart disease per year. ${ }^{15}$

In the United States, a reduction in salt intake of $3 \mathrm{~g}$ per day would reduce the annual number of new cases of cardiovascular disease by approximately 10\% (around 60 000-120 000 fewer cases of coronary heart disease, 32 000-66 000 strokes, and 54 000-99 000 heart attacks) with a corresponding reduction in all cause mortality. ${ }^{\mathrm{w} 11}$ The expected reductions in vascular events would be comparable with those currently projected for interventions targeting tobacco, obesity, or primary prevention with statins and antihypertensives. ${ }^{\text {w5 }}$

\section{Changing salt policies and perceived barriers}

As with tobacco, some vested interests in the salt and food industries are fighting a rearguard action. The salt industry is reluctant to facilitate a reduction in salt intake across populations, but not because their major market is in food; less than $10 \%$ of the salt sold worldwide enters the food chain. Yet the use of salt in food is indirectly a source of revenue for food and beverage manufacturers more widely. High salt intake downregulates taste buds for saltiness, and makes food more palatable, thus increasing demand. Salt in meat products, in conjunction with other water binding chemicals, increases the amount of water that can be bound into the meat, increasing weight by up to $20 \%$ at no cost. High salt intake increases thirst and demand for sugary drinks. ${ }^{10}$ These increase calorie intake, particularly in younger people who are major consumers, thus contributing to obesity. ${ }^{16}$

The UK experience indicates that in the early stages of a salt reduction programme it is possible to take $5-15 \%$ of the salt out of a product gradually without noticeable change in flavour, sales, or complaints about taste. As salt intake falls, the salt taste receptors in the mouth adapt and become more sensitive to lower concentrations of salt within months. ${ }^{17}$ Once salt intake is reduced, people prefer the taste of food with less salt. ${ }^{18}$

Reports of paradoxical increases in cardiovascular risk in those on a low sodium intake have recently sparked some debate. ${ }^{\text {w21-w24 }}$ However, these studies are seriously flawed. ${ }^{\mathrm{w} 25-\mathrm{w} 28}$

The International Council for the Control of Iodine Deficiency Disorders estimates that about 1.5 billion people worldwide live in areas of iodine deficiency. In 1996, in conjunction with WHO and Unicef, they started a universal salt iodisation programme, using salt as a vehicle to deliver supplementary iodine in the diet. If salt intake is reduced, these policies will remain compatible, cost effective, and of great public health benefit, if the level of iodine fortification can be adjusted to changing sodium intake.

Various policy interventions are currently being tested or implemented worldwide through national and international initiatives (table 3) ${ }^{14}$ International schemes have led to high level agreements among many governments for the implementation of national programmes to reduce population dietary salt for the prevention of cardiovascular disease. Salt substitution policies are being tested in China, where this alternative approach might be feasible. However, a regulatory approach is both necessary and acceptable, ${ }^{13}$ as demonstrated in Finland. This is more effective and cost effective than the voluntary approach alone. ${ }^{\mathrm{w} 12}$ 


\section{Conclusions}

Health policy makers and governments have to decide how best to reduce population salt intake at a population level, to save most lives and public money in shrinking economies; likewise, in low and middle income countries with very limited budgets, how best to afford cheaper and effective planning to prevent, ameliorate, and control their rapidly increasing burden of non-communicable diseases.

Changing personal behaviour and choice alone is not an effective or realistic option when the majority of salt is added to food before it is sold and food marketing relies on taste. Furthermore, the commercial addition of salt to food is becoming a global trend as the worldwide food economy changes. A four pronged approach is therefore required and should form the base for a comprehensive policy:

- Communication-establishing and evaluating public awareness campaigns

- Reformulation—setting progressive salt targets for reformulating existing processed food and engaging with the food industry in setting standards for new foods

- Monitoring — surveying population salt intake, progress of reformulation, and effectiveness of communication

- Regulation-engagement with industry, including regulation, to create a level playing field so as not to disadvantage more enlightened and progressive companies

The huge responsibility of food manufacturers in contributing to the epidemic of cardiovascular disease must be acknowledged, and prevention implemented through food reformulation and effective voluntary, market intervention, or mandatory action throughout the industry. ${ }^{19}$ Civil society, governments, academia, and health organisations all have a part to play. Denial and procrastination will be costly in terms of both avoidable illness and expenses.

We thank Robert Beaglehole and the reviewers for helpful and constructive comments.

Contributors: FPC prepared an Expert Opinion paper presented to NICE, took part in discussions, and drafted the manuscript. SC, PL, and KMcP all contributed to the discussions and made substantial contributions to the draft manuscript. FPC acts as guarantor.

Competing interests: All authors have completed the ICMJE uniform disclosure form at www.icmje.org/coi_disclosure.pdf (available on request from the corresponding author) and declare: no support from any organisation for the submitted work; no financial relationships with any organisations that might have an interest in the submitted work in the previous three years. No other relationships or activities that could appear to have influenced the submitted work, apart from FPC who is unpaid member of $\mathrm{CASH}, \mathrm{WASH}$, unpaid technical adviser to $\mathrm{WHO}$ and PAHO, individual member of the National Heart Forum and member of the executive committee and trustee of the British Hypertension Society; $\mathrm{SC}$ who is a trustee of the Heart of Mersey, and PL, KM, and SC who are chief executive, chair, and trustee, respectively, of the UK National Heart Forum. All the authors were members of the NICE cardiovascular disease population prevention guideline development group. This paper does not necessarily reflect the views of NICE nor does it represent the decisions or the stated policy of $\mathrm{WHO}$ and the designations employed and the presentation of material do not imply the expression of any opinion on the part of WHO.

Provenance and peer review: Commissioned, externally peer reviewed.

1 Lopez AD, Mathers CD, Ezzati M, Jamison DT, Murray CJ. Global and regional burden of disease and risk factors, 2001: systematic analysis of population health data. Lancet 2006:367:1747-57.

2 Lewington S, Clarke R, Qizilbash N, Peto R, Collins R. Age-specific relevance of usual blood pressure to vascular mortality: a meta-analysis of individual data for one million adults in 61 prospective studies. Lancet 2002;360:1903-13.

3 Blood Pressure Lowering Treatment Trialists' Collaboration. Effects of different blood pressure lowering regimens on major cardiovascular events: results of prospectively designed overviews of randomised trials. Lancet 2003:362:1527-35.

4 He FJ, MacGregor GA. Effect of modest salt reduction on blood pressure: a meta-analysis of randomized trials. Implications for public health. J Hum Hypert 2002;16:761-70.

5 He FJ, MacGregor GA. How far should salt intake be reduced? Hypertension 2003;42:1093-9.

6 Forte JG, Miguel JM, Miguel MJ, de Padua F, Rose G. Salt and blood pressure: a community trial. J Hum Hypertens 1989:3:179-84.

7 Takahashi Y, Sasaki S, Okubo S, Hayashi M, Tsugane S. Blood pressure change in a free-living population based dietary modification study in Japan. $J$ Hypertens 2006;24:451-8.

8 Strazzullo P. Benefit assessment of dietary salt reduction: while the doctors study, should more people die? J Hypertens 2011;29:829-31.

9 Strazzullo P, D'Elia L, Kandala N-B, Cappuccio FP. Salt intake, stroke, and cardiovascular disease: meta-analysis of prospective studies. BMJ 2009;339:b4567.

10 Karppanen H, Mervaala E. Sodium intake and hypertension. Prog Cardiovasc Dis 2006;49:59-75.

11 Sasaki N. The salt factor in apoplexy and hypertension: epidemiological studies in Japan In: Yamori Y, ed. Prophylactic approach to hypertensive diseases. Raven Press, 1979, pp 467-74.

12 Beaglehole R, Bonita R, Horton R, Adams C, Alleyne G, Asaria P, et al. Priority actions for the non-communicable disease crisis. Lancet 2011;377:1438-47.

13 Cappuccio FP. Salt and cardiovascular disease. BMJ 2007;334:859-60.

14 Webster JL, Dunford EK, Hawkes C, Neal BC. Salt reduction initiatives around the world. J Hypertens 2011;29:1043-50.

15 National Institute for Health and Clinical Excellence. Prevention of cardiovascular disease at population level. NICE public health guidance 25. 2010.

16 Malik VS, Schulze MB, Hu FB. Intake of sugar-sweetened beverages and weight gain: a systematic review. Am J Clin Nutr 2006;84:274-88.

17 Blais CA, Pangborn RM, Borhani NO, Ferrell MF, Prineas RJ, Laing B. Effect of dietary sodium restriction on taste responses to sodium chloride: a longitudinal study. Am J Clin Nutr 1986;44:232-43.

18 Teow BH, Nicolantonio RD, Morgan TO. Sodium chloride preference and recognition threshold in normotensive subjects on high and low salt diet. Clin Exper Hypertens 1985;7:1681-95.

19 Sharma LL, Teret SP, Brownell KD. The food industry and self-regulation: standards to promote success and to avoid public health failures. Am J Public Health 2010;100:240-6.

Accepted: 31 July 2011

Cite this as: BMJ 2011;343:d4995 


\section{Tables}

\section{Table 1| Population dietary salt targets set worldwide}

\begin{tabular}{|c|c|c|}
\hline Country/region & Organisation & $\begin{array}{l}\text { Targets for daily salt intake (g per person per } \\
\text { day) }\end{array}$ \\
\hline Worldwide & WHO & 5 \\
\hline Europe & EC High Level group & $4 \%$ reduction/year over 4 years (by 2012) \\
\hline Austria & $\mathrm{DACH}$ & 6 \\
\hline Belgium & Government & 6 \\
\hline Bulgaria & Government & 5 \\
\hline Cyprus & Government & 5 \\
\hline Czech Republic & Government & 5 \\
\hline Denmark & Government & 5 \\
\hline Estonia & Government & 6 (men), 5 (women) \\
\hline Finland & Government & 7 (men), 6 (women) \\
\hline France & Government & 8 \\
\hline Germany & $\mathrm{DACH}$ & 6 \\
\hline Greece & Government & 5 \\
\hline Hungary & Government & 5 \\
\hline Iceland & Nordic Nutrition & 7 (men), 6 (women) \\
\hline Ireland & Government & 6 (by 2010) \\
\hline Italy & INRAN & 6 \\
\hline Latvia & Government & 5 \\
\hline Lithuania & Government & 5 \\
\hline Netherlands & Industry & 6 \\
\hline Norway & Government & 5 \\
\hline Poland & Government & 6 \\
\hline Portugal & Government & 6 \\
\hline Romania & Government & 5 \\
\hline Slovenia & Government & 5 \\
\hline Spain & Government & 5 \\
\hline Sweden & Nordic Nutrition & 7 (men), 6 (women) \\
\hline Switzerland & Government & 8 \\
\hline UK & Government & 6 (by 2015), 3 (by 2025) \\
\hline Americas & $\mathrm{PAHO} / \mathrm{WHO}$ & 5 (by 2025) \\
\hline Argentina & Government & 6 \\
\hline Barbados & Government & 6 \\
\hline Brazil & Government & 5 \\
\hline Canada & Government & 5.75 (by 2016) \\
\hline Chile & Government & 5 \\
\hline Uruguay & Government & 5 \\
\hline USA & Government & 5.8 \\
\hline \multicolumn{3}{|l|}{ Australasia } \\
\hline Australia & NGO & 6 \\
\hline Fiji & Government & 5 \\
\hline New Zealand & NGO & 6 \\
\hline Singapore & Government & 5 \\
\hline \multicolumn{3}{|l|}{ Asia } \\
\hline China & NGO & 6 \\
\hline Indonesia & Government & 6 \\
\hline
\end{tabular}




\section{Table 1 (continued)}

$\begin{array}{lccc}\text { Country/region } & \text { Organisation } & \text { Targets for daily salt intake (g per person per } \\ \text { day) }\end{array}$

EC=European Commission, DACH=D, Germany, A, Austria, CH, Switzerland, INRAN= National Research Institute for Food and Nutrition, PAHO=Pan American Health Organization, $\mathrm{NGO}=$ non-governmental organisation. Source references available on bmj.com ${ }^{\text {w13-w20 }}$ 


\begin{tabular}{|c|c|c|c|c|c|c|c|}
\hline Country/Region & Leadership & $\begin{array}{l}\text { Documented baseline } \\
\text { levels of salt intake (g per } \\
\text { person per day) }\end{array}$ & Salt in food & $\begin{array}{l}\text { Documented } \\
\text { consumer } \\
\text { behaviours }\end{array}$ & $\begin{array}{l}\text { Monitoring } \\
\text { ongoing }\end{array}$ & Food reformulation & $\begin{array}{l}\text { Consumer } \\
\text { education }\end{array}$ \\
\hline \multicolumn{8}{|l|}{ Europe } \\
\hline Belgium & Government & $11.0^{*}$ & Yes & Yes & Yes & Voluntary & Yes \\
\hline Bulgaria & Government & $12.0 \dagger$ & Yes & & Yes & Voluntary & \\
\hline Czech Republic & Government & $11.0-12.0 \dagger$ & & & & & \\
\hline Cyprus & Government & & & Yes & Yes $\ddagger$ & Voluntary & Yes \\
\hline Denmark & Government & $7.0-11.0^{*}$ & Yes & & Yes & Voluntary & Yes \\
\hline Finland & Government & $7.6-10.0^{*}$ & Yes & & Yes & Voluntary & Yes (NGO) \\
\hline France & Government & $8.4 \dagger$ & Yes & & Yes & Voluntary & Yes \\
\hline Georgia & Government & & & Yesł & & & \\
\hline Hungary & Government & 16.0-18.0† & Yes & Yesł & Yes & Voluntary & Yesł \\
\hline Ireland & Government & $7.4-10.4^{\star}$ & Yes & Yes & Yes & Voluntary & Yes \\
\hline Italy & Government & $10.8 \dagger$ & Yes $\ddagger$ & & Yes & Voluntary & \\
\hline Latvia & Government & & Yes & Yesł & Yes & Voluntary & Yesł \\
\hline Lithuania & Government & $11.0 \dagger$ & & & & Voluntary & Yes $\ddagger$ \\
\hline Netherlands & Industry & $7.6-9.7^{\star}$ & Yes & Yes & Yes & Voluntary & Yes (NGO) \\
\hline Norway & Government & $10.0 \dagger$ & Yesł & & & Voluntary & Yesł \\
\hline Poland & Government & & & & & Voluntary & Yesł \\
\hline Portugal & Government & $11.9 \dagger$ & & & & Mandatory $\ddagger$ & Yes \\
\hline Slovenia & Government & $9.9-13.0^{*}$ & Yes & Yesł & Yes & Voluntary & Yesł \\
\hline Spain & Government & $8.4-11.5^{*}$ & Yesł & & & Voluntary & Yes \\
\hline Sweden & Government & 10.0-12.0† & & & & & \\
\hline Switzerland & Government & $8.1-10.6^{*}$ & Yes $\ddagger$ & Yes & & Voluntary $\ddagger$ & Yes $\ddagger$ \\
\hline UK & Government & $9.5^{\star}$ & Yes & Yes & Yes & Voluntary & Yes \\
\hline Ukraine & Government & & Yes & Yes & & & \\
\hline \multicolumn{8}{|l|}{ Americas } \\
\hline Argentina & Government & $12.5 \dagger$ & Yes & Yesł & Yes & Mandatory $\ddagger$ & \\
\hline Barbados & Government & $12.0-15.0$ & Yes & & Yes & Voluntary & Yes \\
\hline Brazil & Government & $9.6 \dagger$ & Yes & & Yes & Voluntary & \\
\hline Canada & Government & $7.8 \dagger$ & Yes & Yes & Yes & Voluntary & Yes (NGO) \\
\hline Chile & Government & $10.0 \dagger$ & Yes & & & Voluntary & Yes \\
\hline Costa Rica & Government & $7.0 \dagger$ & Yesł & Yesł & Yesł & & \\
\hline Ecuador & Government & $10.0 \dagger$ & & & & & \\
\hline Guatemala & Government & $19.0 \dagger$ & & & & & \\
\hline Mexico & Government & & Yes $\ddagger$ & & Yes & Voluntary $\ddagger$ & \\
\hline United States & Government & $8.6 \dagger$ & Yes & & Yes & Voluntary & Yes (NGO) \\
\hline \multicolumn{8}{|l|}{ Australasia } \\
\hline Australia & NGO & $6.5-12.0^{*}$ & Yes & Yes & Yes & Voluntary & Yes \\
\hline Fiji & Government & $5.2-5.4 \dagger$ & Yesł & Yesł & Yes & Voluntary & Yes \\
\hline Malaysia & NGO & $6.4 \dagger$ & Yes $\ddagger$ & & Yesł & Voluntary & Yes (NGO) \\
\hline New Zealand & NGO & 5.4-7.6† & Yes & Yes & Yes & Voluntary & Yes (NGO) \\
\hline Philippines & Government & & & & Yes $\ddagger$ & & \\
\hline Singapore & Government & $8.8 \dagger$ & Yes & Yesł & & Voluntary & Yes \\
\hline Thailand & Government & & & Yesł & Yes $\ddagger$ & & \\
\hline Vietnam & Government & & & Yesł & Yesł & & \\
\hline \multicolumn{8}{|l|}{ Asia } \\
\hline Bangladesh & Government & & & Yesł & Yesł & & \\
\hline China & NGO & $12.0 \dagger$ & & & & & Yes \\
\hline
\end{tabular}


Table 2 (continued)

\begin{tabular}{|c|c|c|c|c|c|c|c|}
\hline Country/Region & Leadership & $\begin{array}{l}\text { Documented baseline } \\
\text { levels of salt intake (g per } \\
\text { person per day) }\end{array}$ & Salt in food & $\begin{array}{l}\text { Documented } \\
\text { consumer } \\
\text { behaviours }\end{array}$ & $\begin{array}{l}\text { Monitoring } \\
\text { ongoing }\end{array}$ & Food reformulation & $\begin{array}{l}\text { Consumer } \\
\text { education }\end{array}$ \\
\hline India & Government & & & Yesł & Yesł & & \\
\hline Iran & Government & & & & Yesł & & \\
\hline Japan & NGO & $13.2 \dagger$ & & & Yes & & Yes (NGO) \\
\hline Kuwait & Government & & & & Yesł & & \\
\hline South Korea & Government & & Yes & Yes & Yesł & & \\
\hline \multicolumn{8}{|l|}{ Africa } \\
\hline South Africa & Government & & Yes & & Yesł & & \\
\hline
\end{tabular}

$\mathrm{NGO}=$ non-governmental organisation.

*24 h urine.

†Dietary survey.

$\ddagger$ Planned.

Source references available on bmj.com. ${ }^{\text {w13-w20 }}$ 
Table 3| Policy options for reduction in population salt intake

\begin{tabular}{|c|c|c|c|}
\hline Policy options & Evidence base & Synergies & $\begin{array}{l}\text { Likely salt reduction (per person } \\
\text { per day) }\end{array}$ \\
\hline $\begin{array}{l}\text { Professional education and health } \\
\text { promotion }\end{array}$ & Primary care in UK & - & Negligible \\
\hline Social marketing & UK, New York City & Politically popular & $0.1 \mathrm{~g}^{*}$ \\
\hline Labelling & Finland, European Community & Will also benefit fat and sugar & $0.5 \mathrm{~g} \dagger$ \\
\hline Product reformulation & Finland, UK & Will also benefit fat and sugar & $1 \mathrm{~g} \ddagger$ \\
\hline Substitution & China & - & Not reported \\
\hline Taxation & Finland, New York City & Consistent with fat and sugar tax & $2 \mathrm{~g} \dagger$ \\
\hline Regulation and marketing control & $\begin{array}{l}\text { Finland, Belgium and Italy (bread), New } \\
\text { York City }\end{array}$ & $\begin{array}{l}\text { Greatest benefit in deprived } \\
\text { groups-reduce inequalities }\end{array}$ & $3 \mathrm{~g} \dagger$ \\
\hline
\end{tabular}

*Estimated, no data available.

†Data from Finland.

‡Data from Finland and Food Standards Agency of England and Wales. 